\title{
New data on gersdorffite and associated minerals from the Peloritani Mountains (Sicily, Italy)
}

\author{
Daniela Mauro ${ }^{1}$, Cristian Biagioni ${ }^{1}$, and Federica Zaccarini $^{2}$ \\ ${ }^{1}$ Dipartimento di Scienze della Terra, Università di Pisa, Via Santa Maria 53, 56126 Pisa, Italy \\ ${ }^{2}$ Department of Applied Geological Sciences and Geophysics, University of Leoben, \\ Peter Tunner Str. 5, 8700 Leoben, Austria
}

Correspondence: Daniela Mauro (daniela.mauro@unipi.it)

Received: 1 June 2021 - Revised: 8 October 2021 - Accepted: 16 October 2021 - Published: 19 November 2021

\begin{abstract}
Gersdorffite, ideally NiAsS, and associated minerals from Contrada Zillì (Peloritani Mountains, Sicily, Italy) have been characterized through electron microprobe analysis and X-ray diffraction. Primary minerals, hosted in quartz veins, are represented by gersdorffite, tetrahedrite-(Fe), and chalcopyrite with minor pyrite and galena. Rare aikinite inclusions were observed in tetrahedrite-(Fe) and chalcopyrite. Gersdorffite occurs as euhedral to subhedral crystals, up to $1 \mathrm{~mm}$ in size, with ( $\mathrm{Sb}, \mathrm{Bi}$ )-enriched cores and ( $\mathrm{Fe}, \mathrm{As}$ )-enriched rims. Its chemical composition is $\left(\mathrm{Ni}_{0.79-0.95} \mathrm{Fe}_{0.18-0.04} \mathrm{Co}_{0.04-0.01}\right)\left(\mathrm{As}_{0.90-1.03} \mathrm{Sb}_{0.10-0.00} \mathrm{Bi}_{0.02-0.00}\right) \mathrm{S}_{0.98-0.92}$. It crystallizes in the space group $P 2{ }_{1} 3$, with unit-cell parameters $a=5.6968(7) \AA, V=184.88(7) \AA^{3}$, and $Z=4$, and its crystal structure was refined down to $R_{1}=0.035$. Associated tetrahedrite- $(\mathrm{Fe})$ has chemical formula $\left(\mathrm{Cu}_{5.79} \mathrm{Ag}_{0.07}\right)_{\Sigma 5.86}\left(\mathrm{Cu}_{3.96} \mathrm{Fe}_{1.59} \mathrm{Zn}_{0.45}\right)_{\Sigma 6.00}\left(\mathrm{Sb}_{3.95} \mathrm{As}_{0.17} \mathrm{Bi}_{0.03}\right)_{\Sigma 4.15} \mathrm{~S}_{13.06}$, with unit-cell parameters $a=10.3815(10) \AA, V=1118.9(3) \AA^{3}$, and space group $I-43 m$. Its crystal structure was refined to $R_{1}=0.027$. Textural and crystallographic data suggest a polyphasic crystallization of gersdorffite under low-temperature conditions.
\end{abstract}

\section{Introduction}

The Peloritani Mountains, in northeastern Sicily (Italy), are the southernmost sector of the Calabria-Peloritani Arc, an arc-like structure connecting the Apennines and the Maghrebian Chain and bounded by the Pollino line, in the north, and the Taormina line, in the south (Messina et al., 2004, and references therein). The area of the Peloritani Mountains has been known for the occurrence of several polymetallic $\mathrm{Pb}-\mathrm{Zn}-\mathrm{Fe}-\mathrm{As}-\mathrm{Sb}-\mathrm{Cu}-\mathrm{Ag}-\mathrm{W}-(\mathrm{Au})$ ore deposits exploited since pre-Roman times; the last prospections were performed in the 1980s, and currently all mining activity has ceased (Saccà et al., 2015, and references therein). The first scientific contributions date back to the second half of the 19th century and the beginning of the 20th century (e.g., Seguenza, 1856; Jervis, 1881; La Valle, 1898, 1899; Traina, 1905). After these pioneering studies, further contributions were mainly given around the half of the 20th century (e.g., Bossolasco and Bonetti, 1940; Rodolico, 1940; Baldanza, 1948; Musumeci, 1958) and between the end of the 1970s and the 1980s (Donati et al., 1978; Ferla, 1982/1983; Triscari and Saccà, 1984; Triscari, 1985; Oteri et al., 1986). The occurrence of Ni minerals in the ore deposits from the Peloritani Mountains was first reported by Seguenza (1856), who identified ullmannite, NiSbS. Later, La Valle (1898) reported annabergite, $\mathrm{Ni}_{3}\left(\mathrm{AsO}_{4}\right)_{2} \cdot 8 \mathrm{H}_{2} \mathrm{O}$, from Pizzo Cipolla, near Mandanici. The only modern description of Ni minerals was given by Triscari (1985), who studied gersdorffite from Contrada Zillì, in the Fiumedinisi area (Messina Province), in association with a tetrahedrite-group mineral.

Contrada Zillì is considered to belong to the northern sector of the San Carlo mine (Fig. 1). The complex mineralogy of this area has been discussed by Donati et al. (1978), Triscari and Saccà (1982), and Oteri et al. (1986). The ore bodies are hosted within the Mandanici Unit, a tectonic slice formed by low-to-medium-grade metamorphic rocks affected by Variscan metamorphism; Alpine orogeny is associated with cataclastic-to-mylonitic processes only (Carbone et al. 2007, and references therein). At the San Carlo mine, the ore deposit is represented by quartz-carbonate veins with Ag- 


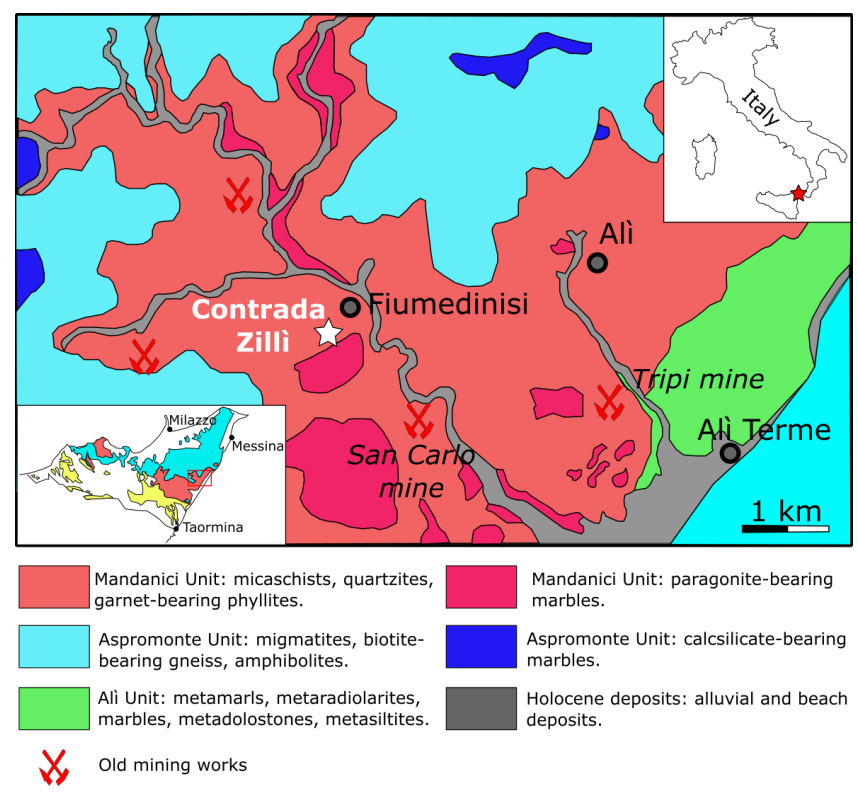

Figure 1. Geological sketch of the Fiumedinisi area (modified after Oteri et al., 1986). The inset on the left shows the location of the studied area (red box) within the Peloritani Mountains. In the inset, the main tectonic units are shown: light blue = Aspromonte Unit; pink $=$ Mandanici Unit; yellow $=$ South Peloritan Complex (after Ferla and Omenetto, 2000).

bearing tetrahedrite-group minerals, chalcopyrite, bournonite, and minor pyrite, galena, sphalerite, stromeyerite, pentlandite, and bismuthinite (e.g., Oteri et al., 1986).

A sampling recently performed in Contrada Zillì allowed for the collection of new specimens whose study permitted a new crystal-chemical investigation on gersdorffite and tetrahedrite-(Fe) from this sector of northeastern Sicily, refining our knowledge about the ore mineralogy of the Peloritani Mountains. The results of this study are reported and discussed in this paper.

\section{Experimental}

In hand specimen, the studied samples are characterized by aggregates of metallic grey masses, up to $3 \times 1.5 \mathrm{~cm}$ in size, with minor metallic patches of chalcopyrite, yellow in color, in a gangue formed by quartz only (Fig. 2a). Within the grey masses and in quartz, euhedral to subhedral octahedral grey crystals of gersdorffite were observed (Fig. 2b).

Mineralogical and textural features were investigated using polished samples with reflected light microscopy through a Zeiss Axioplan microscope (Dipartimento di Scienze della Terra, University of Pisa, Italy). Backscattered electron images and chemical data were collected using a FEI Quanta 450 ESEM FEG equipped with a Bruker QUANTAX XFlash detector 6|10 operating in EDS mode (C.I.S.U.P., University of Pisa, Italy). Quantitative chemical data were col- lected using a Superprobe JEOL JXA 8200 electron microprobe at the "Eugen F. Stumpfl" laboratory, Leoben University, Austria. The analytical conditions were the following: WDS mode, accelerating voltage $20 \mathrm{kV}$, and beam current $10 \mathrm{nA}$, beam size $1 \mu \mathrm{m}$. The following standards (element, emission line) were used: pyrite $(\mathrm{Fe} K \alpha, \mathrm{S} K \alpha)$, skutterudite (As $L \alpha, \operatorname{Co} K \alpha)$, millerite $(\mathrm{Ni} K \alpha)$, chalcopyrite $(\mathrm{Cu} K \alpha)$, sphalerite $(\mathrm{Zn} K \alpha)$, galena $(\mathrm{Pb} M \alpha)$, electrum $(\mathrm{Ag} L \alpha)$, stibnite $(\mathrm{Sb} L \alpha)$, and $\mathrm{Bi}$ metal $(\mathrm{Bi} M \alpha)$. The following diffracting crystals were used: TAP for As; LIF for $\mathrm{Fe}, \mathrm{Ni}, \mathrm{Co}, \mathrm{Cu}$, and $\mathrm{Zn}$; PET for $\mathrm{S}, \mathrm{Pb}, \mathrm{Ag}, \mathrm{Bi}$, and $\mathrm{Sb}$. The ZAF routine was applied for the correction of the recorded raw data. Counting times were $15 \mathrm{~s}$ for peak and $5 \mathrm{~s}$ for backgrounds. X-ray maps for selected elements were collected through the same analytical condition used for electron microprobe analyses.

Mineral identification was performed on the basis of Xray powder diffraction using a $114.6 \mathrm{~mm}$ Gandolfi camera and Ni-filtered $\mathrm{Cu} K \alpha$ radiation. Single-crystal X-ray diffraction data were collected using a Bruker Smart Breeze diffractometer operating at $50 \mathrm{kV}$ and $30 \mathrm{~mA}$ and equipped with an air-cooled Photon II CCD detector. Graphitemonochromatized $\mathrm{Mo} K \alpha$ radiation was used. The detectorto-crystal working distance was set to $50 \mathrm{~mm}$. Intensity data were integrated and corrected for Lorentz, polarization, background effects, and absorption using the package of software APEX 3 (Bruker AXS Inc., 2016). Crystal structure refinements were performed using Shelxl-2018 (Sheldrick, 2015); neutral scattering curves were taken from the International Tables for Crystallography (Wilson, 1992). Crystallographic Information File (CIF) data are available in the Supplement.

\section{Results}

\subsection{Ore mineralogy}

The mineralogical characterization of the specimens from Contrada Zillì pointed out the association with chalcopyrite, gersdorffite, and tetrahedrite-(Fe), along with minor pyrite, galena, and aikinite. Chalcopyrite occurs as anhedral grains, and it is the third most abundant ore mineral in the studied samples, after gersdorffite and tetrahedrite-(Fe). Electron microprobe data for these two latter minerals are given in Tables 1 and 2, respectively; they will be described in detail below (see Sect. 3.1.1 and 3.1.2). Pyrite is relatively common, in subhedral to anhedral individuals, up to $0.5 \mathrm{~mm}$ across. Galena was observed as rare anhedral grains. Finally, aikinite was identified as anhedral grains, with rounded edges, less than $50 \mu \mathrm{m}$ in size, hosted in chalcopyrite and tetrahedrite$(\mathrm{Fe})$; in some cases, it is intimately associated with galena. Its chemical composition is the following (in wt $\%$ - average of three spot analyses): $\mathrm{Cu} 11.33(14), \mathrm{Pb} 35.53(35), \mathrm{Bi}$ 36.93(61), S 16.92(4), total 100.74(41). Antimony and Ag were sought, but they were found below the detection limit. 

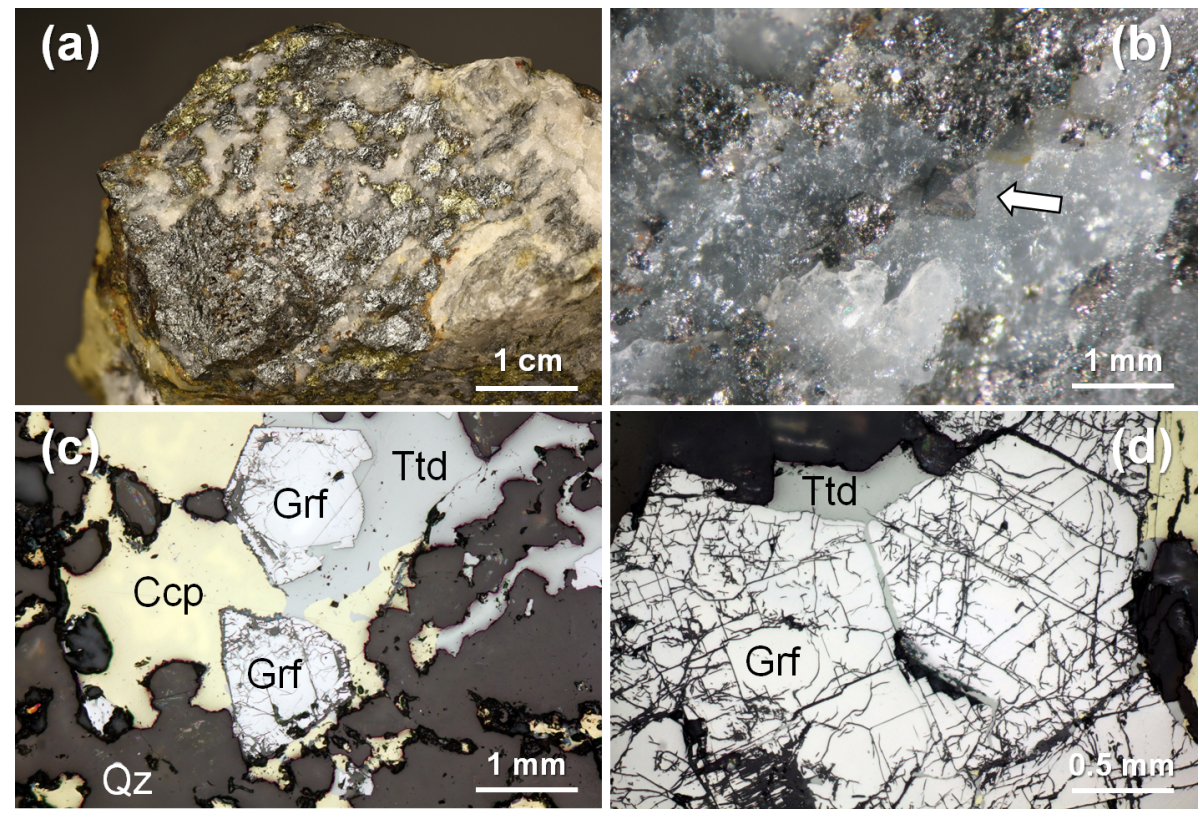

Figure 2. The studied specimen from Contrada Zillì, Fiumedinisi, Messina, Sicily (Italy). (a) Black compact metallic mass of tetrahedrite(Fe) with admixed minor gersdorffite and yellow chalcopyrite in quartz. (b) Gersdorffite, octahedral crystal (indicated by the white arrow), less than $1 \mathrm{~mm}$ in size, in quartz. (c) Subhedral crystals of gersdorffite (Grf) associated with chalcopyrite (Ccp) and tetrahedrite-(Fe) (Ttd), in quartz (Qz). Reflected light microscopy, Nicol //. (d) Details of subhedral crystals of gersdorffite showing its good $\{100\}$ cleavage. Reflected light microscopy, Nicol //.

Its chemical formula, based on three cations per formula unit, is (with rounding errors) $\mathrm{Cu}_{1.02(1)} \mathrm{Pb}_{0.98(2)} \mathrm{Bi}_{1.01(1)} \mathrm{S}_{3.01(1)}$, in good agreement with the ideal one.

\subsubsection{Gersdorffite}

Gersdorffite occurs as euhedral to anhedral grains (Fig. 2c), up to $1 \mathrm{~mm}$ in size. Sometimes, $\{100\}$ cleavage can be observed (Fig. 2d). Along these surfaces, alteration products, represented by a low-crystalline $(\mathrm{Fe}, \mathrm{Cu}, \mathrm{Co})$-bearing $\mathrm{Ni}$ arsenate, occur. Backscattered electron (BSE) images collected on several euhedral crystals of gersdorffite showed their zoning (Fig. 3a). Electron microprobe data are given in Table 1 . Figure 3 also shows the three lines along which analyses were performed using steps of $10 \mu \mathrm{m}$. The variation of $\mathrm{Fe} /(\mathrm{Fe}+\mathrm{Co}+\mathrm{Ni})$ and the $\mathrm{As} /(\mathrm{S}+\mathrm{As}+\mathrm{Sb}+\mathrm{Bi})$ atomic ratios is also shown (Fig. 3b-d). The compositional variability of the studied gersdorffite can be described using triangular $\mathrm{Ni}-$ $\mathrm{Co}-\mathrm{Fe}$ and $\mathrm{Sb}-\mathrm{As}-\mathrm{S}$ diagrams (Fig. 4). Nickel is mainly substituted by Fe, with only minor amounts of Co (Fig. 4a). Such a $\mathrm{Ni}^{2+} \leftrightarrow \mathrm{Fe}^{2+}$ substitution is supported by the relation between these two transition elements (Fig. 5a); moreover, a slight Co decrease is coupled with an increase in $\mathrm{Ni}$ content (Fig. 5a). The $\mathrm{Fe} /(\mathrm{Fe}+\mathrm{Co}+\mathrm{Ni})$ atomic ratios obtained along the three lines shown in Fig. 3, as well as the X-ray maps reported in Fig. 6, suggest that $\mathrm{Fe}$ is mainly concentrated in the crystal rims. Figure $4 \mathrm{~b}$ shows that all analyses fall around the $50: 50 \mathrm{As} / \mathrm{S}$ boundary, in agreement with the ideal sto- ichiometry of gersdorffite. These two elements are replaced by minor $\mathrm{Sb}$; minor amounts of $\mathrm{Bi}$ are not shown in Fig. $4 \mathrm{~b}$. Antimony is preferentially hosted in the crystal core (Fig. 6), substituting As (Fig. 5b). X-ray maps revealed the As enrichment of crystal rims, coupled with the Fe enrichment. Figure $5 \mathrm{c}$ reveals a positive correlation between $\mathrm{As}$ and $\mathrm{Fe}$ for As content higher than $\sim 1 \mathrm{apfu}$; lower As content is characterized by rather constant $\mathrm{Fe}$ contents. Finally, X-ray maps suggest that $\mathrm{Bi}$ is more abundant in the brightest domains occurring in BSE images (Fig. 6).

According to Table 1, the general chemical formula of gersdorffite from Contrada Zillì, on the basis of 3 atoms per formula unit (apfu), can be written as $\left(\mathrm{Ni}_{0.79-0.95} \mathrm{Fe}_{0.18-0.04} \mathrm{Co}_{0.04-0.01}\right)\left(\mathrm{As}_{0.90-1.03} \mathrm{Sb}_{0.10-0.00}\right.$ $\left.\mathrm{Bi}_{0.02-0.00}\right) \mathrm{S}_{0.98-0.92}$. Its unit-cell parameters are $a=$ 5.6968(7) $\AA$ and $V=184.88(7) \AA^{3}$. The crystal structure was refined in the space group $P 2_{1} 3$, in agreement with systematic absences, starting from the atomic coordinates given by Bayliss and Stephenson (1967), to $R_{1}=0.0349$ for 148 unique reflections with $F_{o}>4 \sigma\left(F_{o}\right)$ and 12 refined parameters (Table 3). The occurrence of racemic twin was modeled, pointing to a ratio $0.72: 0.28$. The s.o.f. (site occupancy factor) at the Ni site was fixed to 1 . Indeed, minor Co $(Z=27)$ and $\mathrm{Fe}(Z=26)$ have very similar scattering factors as $\mathrm{Ni}$ $(Z=28)$. Atomic coordinates and equivalent isotropic displacement parameters are given in Table 4. Nickel is coordinated by three $\mathrm{S}$ atoms and three As atoms. The following distances were observed: Ni-S 2.349(2) $\AA$ and Ni- 
Table 1. Selected electron microprobe analyses of gersdorffite.

\begin{tabular}{lrrrrrrrrrrr}
\hline Element & wt $\%$ & wt $\%$ & wt $\%$ & wt $\%$ & wt $\%$ & wt $\%$ & wt \% & wt \% & wt \% & wt \% & wt \% \\
\hline $\mathrm{Ni}$ & 33.20 & 33.04 & 32.76 & 32.32 & 31.79 & 31.66 & 31.57 & 31.25 & 30.76 & 28.32 & 27.88 \\
$\mathrm{Co}$ & 0.81 & 0.60 & 0.77 & 0.72 & 1.03 & 1.08 & 0.86 & 0.81 & 0.49 & 1.35 & 1.28 \\
$\mathrm{Fe}$ & 1.71 & 1.46 & 1.20 & 1.41 & 1.67 & 3.28 & 2.37 & 1.60 & 1.96 & 5.78 & 6.00 \\
$\mathrm{Bi}$ & 0.03 & 0.90 & 0.22 & 1.06 & 0.18 & 0.10 & 0.35 & 2.76 & 2.32 & b.d.1. & b.d.1. \\
$\mathrm{Sb}$ & 2.79 & 5.09 & 3.07 & 4.81 & 3.55 & 2.01 & 1.79 & 6.72 & 6.32 & b.d.1. & 0.05 \\
$\mathrm{As}$ & 44.11 & 42.33 & 42.92 & 41.22 & 43.93 & 44.71 & 43.60 & 38.35 & 41.94 & 46.47 & 45.96 \\
$\mathrm{~S}$ & 18.88 & 18.22 & 18.30 & 18.02 & 17.54 & 18.99 & 18.54 & 17.84 & 16.92 & 18.57 & 18.49 \\
\hline Total & 101.53 & 101.64 & 99.24 & 99.56 & 99.69 & 101.53 & 99.08 & 99.33 & 100.71 & 100.49 & 99.66 \\
\hline Element & apfu & apfu & apfu & apfu & apfu & apfu & apfu & apfu & apfu & apfu & apfu \\
\hline Ni & 0.94 & 0.95 & 0.95 & 0.95 & 0.93 & 0.88 & 0.91 & 0.93 & 0.92 & 0.80 & 0.79 \\
$\mathrm{Co}$ & 0.02 & 0.02 & 0.02 & 0.02 & 0.03 & 0.03 & 0.02 & 0.02 & 0.01 & 0.04 & 0.04 \\
$\mathrm{Fe}$ & 0.05 & 0.04 & 0.04 & 0.04 & 0.05 & 0.10 & 0.07 & 0.05 & 0.06 & 0.17 & 0.18 \\
$\mathrm{Bi}$ & - & 0.01 & - & 0.01 & - & - & - & 0.02 & 0.02 & - & - \\
$\mathrm{Sb}$ & 0.04 & 0.07 & 0.04 & 0.07 & 0.05 & 0.03 & 0.02 & 0.10 & 0.09 & - & - \\
$\mathrm{As}$ & 0.98 & 0.95 & 0.97 & 0.95 & 1.00 & 0.99 & 0.99 & 0.90 & 0.98 & 1.03 & 1.03 \\
$\mathrm{~S}$ & 0.98 & 0.96 & 0.97 & 0.97 & 0.94 & 0.98 & 0.98 & 0.98 & 0.92 & 0.96 & 0.96 \\
\hline
\end{tabular}

Note: b.d.l. $=$ below detection limits. Detection limits were (in wt $\%$ ): $\mathrm{Ni}=0.015 ; \mathrm{Co}=0.015 ; \mathrm{Fe}=0.015 ; \mathrm{Bi}=0.04 ; \mathrm{Sb}=0.035 ; \mathrm{As}=0.02 ; \mathrm{S}=$ 0.01. apfu $=$ atoms per formula unit, on the basis of 3 apfu.
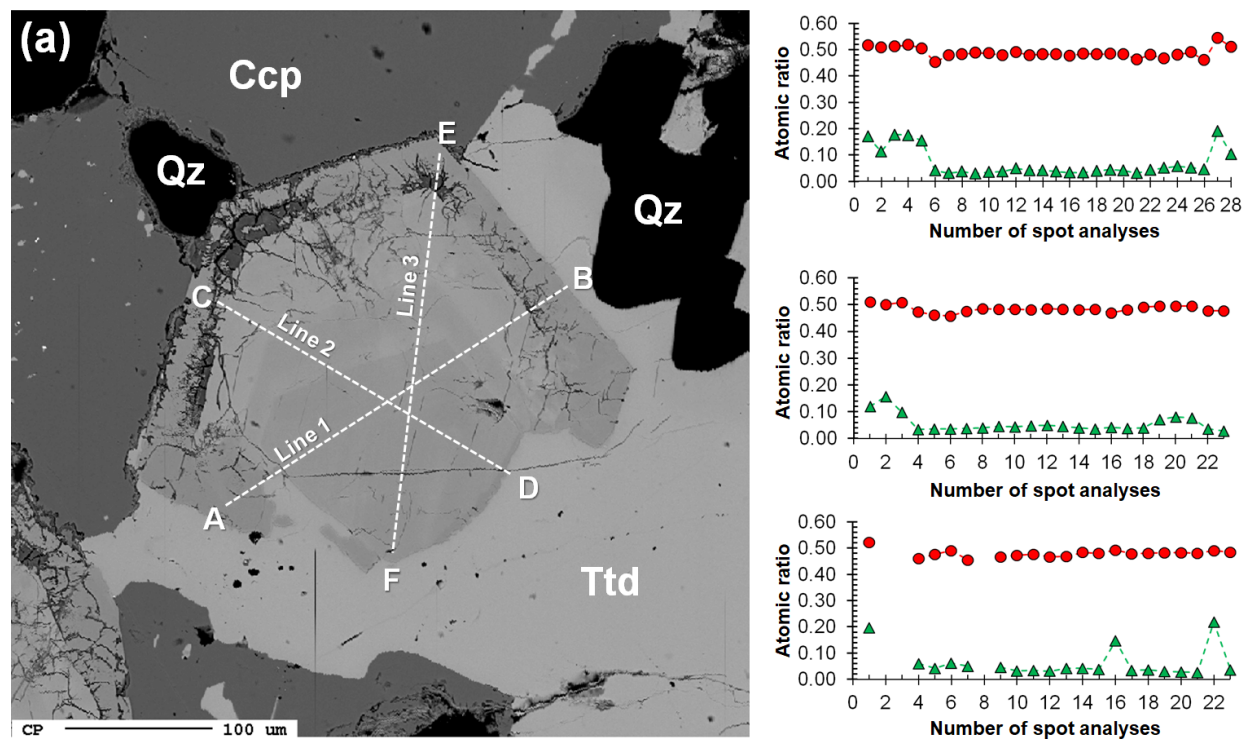

(b)

(c)

(d)

Figure 3. (a) Backscattered electron image of a zoned crystal of gersdorffite (see Fig. 2c) associated with chalcopyrite (Ccp), tetrahedrite(Fe) $(\mathrm{Ttd})$, and quartz (Qz). Dashed lines A-B, C-D, and E-F represent the transects where spot analyses were performed using a step of $10 \mu \mathrm{m}$. Atomic ratios $\mathrm{As} /(\mathrm{S}+\mathrm{As}+\mathrm{Sb}+\mathrm{Bi})$ and $\mathrm{Fe} /(\mathrm{Fe}+\mathrm{Co}+\mathrm{Ni})$ along the lines $\mathrm{A}-\mathrm{B}(\mathbf{b}), \mathrm{C}-\mathrm{D}(\mathbf{c})$, and $\mathrm{E}-\mathrm{F}(\mathbf{d})$ are shown as red circles and green triangles, respectively. Omitted points in (d) correspond to weathering products along the E-F line.

As 2.405(2) $\AA$ (Table 5). Whereas the latter is close to the value reported by Bayliss and Stephenson (1967), the former is slightly longer. Indeed, the As site was found to have a pure As occupancy, whereas the $\mathrm{S}$ site was refined as a mixed (S, As) site, with a refined s.o.f. $\left(\mathrm{S}_{0.86} \mathrm{As}_{0.14}\right)$. Actually, the refined As content is higher than that measured through electron microprobe analysis, resulting in the composition $\left(\mathrm{As}_{1.14} \mathrm{~S}_{0.86}\right)$. However, the occurrence of minor $\mathrm{Sb}$ has to be taken into account. The refined site scattering at the $\mathrm{S}$ and As sites is 51.38 electrons per formula unit (epfu), agreeing with an ideal population $\left(\mathrm{S}_{0.95} \mathrm{As}_{0.95} \mathrm{Sb}_{0.10}\right)$ (corresponding to 51.65 epfu). Finally, the As-S distance is $2.313(4) \AA$, to be compared with those observed in other related sulfarsenides, e.g., in cobaltite, CoAsS, i.e., 2.292(1) ̊̊ (Fleet and Burns, 1990), and gersdorffite refined by Bayliss and Stephenson (1967), i.e., 2.306(10) ̊̊. 
Table 2. Electron microprobe analyses of tetrahedrite-(Fe).

\begin{tabular}{lrrr}
\hline Element & wt $\%(n=9)$ & Range & SD $(\sigma)$ \\
\hline $\mathrm{Cu}$ & 37.34 & $36.91-37.84$ & 0.30 \\
$\mathrm{Ag}$ & 0.48 & $0.34-0.57$ & 0.08 \\
$\mathrm{Fe}$ & 5.34 & $5.23-5.43$ & 0.06 \\
$\mathrm{Zn}$ & 1.77 & $1.69-1.85$ & 0.05 \\
$\mathrm{As}$ & 0.75 & $0.70-0.82$ & 0.04 \\
$\mathrm{Sb}$ & 28.96 & $28.46-29.54$ & 0.37 \\
$\mathrm{Bi}$ & 0.38 & $0.11-0.78$ & 0.26 \\
$\mathrm{~S}$ & 25.24 & $24.99-25.44$ & 0.16 \\
\hline $\mathrm{Total}$ & 100.26 & $99.24-101.31$ & 0.68 \\
\hline $\mathrm{Element} *$ & $\mathrm{apfu}$ & Range & $\mathrm{SD}(\sigma)$ \\
\hline $\mathrm{Cu}$ & 9.75 & $9.69-9.80$ & 0.04 \\
$\mathrm{Ag}$ & 0.07 & $0.05-0.09$ & 0.01 \\
$\mathrm{Fe}$ & 1.59 & $1.57-1.60$ & 0.01 \\
$\mathrm{Zn}$ & 0.45 & $0.43-0.47$ & 0.01 \\
$\mathrm{As}$ & 0.17 & $0.14-0.18$ & 0.01 \\
$\mathrm{Sb}$ & 3.95 & $3.88-4.03$ & 0.05 \\
$\mathrm{Bi}$ & 0.03 & $0.01-0.06$ & 0.02 \\
$\mathrm{~S}$ & 13.06 & $12.96-13.17$ & 0.07 \\
\hline
\end{tabular}

* Calculated on the basis of $\Sigma M e=16$ apfu. Detection limits as in Table 1. For additional elements, the limits (in wt \%) were the following: $\mathrm{Cu}=0.015, \mathrm{Ag}=0.025$, and $\mathrm{Zn}=0.015 . \mathrm{SD}-$ standard deviation.

The X-ray powder diffraction pattern of gersdorffite from Contrada Zillì confirmed the results of the single-crystal Xray diffraction study. Indeed, the identification of the different structural varieties of gersdorffite, i.e., ordered $P 2_{1} 3$ ullmannite type (Bayliss and Stephenson, 1967); disordered $P a 3$ pyrite type (Bayliss, 1968); or distorted disordered $P 1$ pyrite type, later interpreted as a twinned $\mathrm{Pca} 2_{1}$ structure (Bayliss and Stephenson, 1968; Bayliss, 1982), is possible based on the occurrence of the 001 and 011 reflections in the X-ray diffraction patterns (Bayliss, 1969). In the studied sample, only the 011 reflection (at $4.03 \AA$ ) was observed, whereas the 001 reflection was found to be absent; this is fully consistent with the $P 2{ }_{1} 3$ space group.

\subsubsection{Tetrahedrite-(Fe)}

Tetrahedrite-(Fe) forms anhedral grains. BSE images show its homogeneity (Fig. 3a). Quantitative chemical results are given in Table 2. The corresponding chemical formula, normalized on the basis of $\Sigma M e=16 \mathrm{apfu}$, is $\left(\mathrm{Cu}_{5.79} \mathrm{Ag}_{0.07}\right)_{\Sigma 5.86}\left(\mathrm{Cu}_{3.96} \mathrm{Fe}_{1.59} \mathrm{Zn}_{0.45}\right)_{\Sigma 6.00}\left(\mathrm{Sb}_{3.95} \mathrm{As}_{0.17}\right.$ $\left.\mathrm{Bi}_{0.03}\right)_{\Sigma 4.15} \mathrm{~S}_{13.06}$, allowing its classification as tetrahedrite$(\mathrm{Fe})$, in agreement with the nomenclature of tetrahedritegroup minerals (Biagioni et al., 2020a). Unit-cell parameters of tetrahedrite- $(\mathrm{Fe})$ are $a=10.3815(10) \AA, V=$ $1118.9(3) \AA^{3}$, and the space group is $I-43 m$. The crystal structure of tetrahedrite-(Fe) was refined starting from the structural model of tetrahedrite given by Johnson and Burnham (1985). The occurrence of racemic twin was modeled (twin ratio 99:1). The following neutral scattering curves were used: $\mathrm{Cu}$ vs. $\square$ at $M(2)$ and $M(1)$, Sb vs. As at $X(3)$, and $S$ at $S(1)$ and $S(2)$ sites. The anisotropic structural model converged to $R_{1}=0.0270$ for 342 unique reflections with $F_{o}>4 \sigma\left(F_{o}\right)$ and 22 refined parameters (Table 3$)$. Atomic coordinates and equivalent isotropic displacement parameters are given in Table 4. Selected bond distances are given in Table 5. The crystal structure of tetrahedrite-(Fe) from Contrada Zillì agrees with the general features of the members of the tetrahedrite isotypic group. It can be described as a framework of corner-sharing $M(1)$-centered tetrahedra, with cages hosting $\mathrm{S}(2)$-centered $M(2)$ octahedra and four $X(3) \mathrm{S}(1)_{3}$ trigonal pyramids (e.g., Biagioni et al., 2020a).

In tetrahedrite-(Fe) from Contrada Zillì, the triangularly coordinated $M(2)$ site has an average $<\mathrm{Me}-\mathrm{S}>$ bond distance of $2.265 \AA$. Based on the chemical data and normalizing the occupancy of $(\mathrm{Cu}+\mathrm{Ag})=6 \mathrm{apfu}$, the idealized site population at the $M(2)$ site should be $\left(\mathrm{Cu}_{5.92} \mathrm{Ag}_{0.08}\right)_{\Sigma 6.00}$. This site population corresponds to 29.24 electrons per site, in agreement with the refined site scattering, i.e., 29.25 electrons. Bond-valence sum (BVS) at $M(2)$, calculated using the bond parameters by Brese and O'Keeffe (1991), is 1.01 valence units (v.u.). The relatively large $U_{\text {eq }}$ value at this position is probably related to the actual splitting of this site into two flat pyramidal subsites, as previously noted by some authors (e.g., Andreasen et al., 2008; Welch et al., 2018). The tetrahedrally coordinated $M(1)$ site has an average $<\mathrm{Me}-\mathrm{S}>$ bond distance of $2.335 \AA$. This value agrees with previous results on $\mathrm{Fe}$-bearing tetrahedrite-group minerals (e.g., Andreasen et al., 2008); its BVS, 1.56 v.u., is larger than the expected value of 1.33 v.u. Such an overbonding of tetrahedrally coordinated cations in the crystal structure of tetrahedrite-group minerals was reported by previous authors (e.g., Biagioni et al., 2020b). The $X(3)$ site has an average bond distance of $2.428 \AA$, fully consistent with a dominant $\mathrm{Sb}$ occupancy. The corresponding BVS value is $3.15 \mathrm{v} . \mathrm{u}$. Its refined site scattering at the $X(3)$ site gives 49.74 electrons in agreement with the ideal one, i.e., 50.60 electrons per site. The S(1) site is four-fold coordinated, being bonded to two $M(1)$, one $M(2)$, and one $X(3)$. Its BVS is 2.15 v.u. $\mathrm{S}(2)$ is octahedrally coordinated by atoms hosted at $M(2)$ sites, with a BVS of 2.10 v.u. Both sites are fully occupied by $\mathrm{S}$ atoms.

\section{Discussion}

Gersdorffite from Contrada Zillì represents the first crystalchemically well-characterized Italian occurrence of this nickel sulfarsenide, reported since the end of the 19th century and then found in several localities (e.g., Lovisato, 1894; Artini, 1903; Dessau, 1936; Triscari, 1985; Benvenuti, 1991; Carrozzini et al., 1991; Garuti et al., 2001; Moroni et al., 2019). However, only in the paper by Triscari (1985) is a quite full set of chemical and crystallographic data of gersdorffite given, along with some data on associated 
Table 3. Summary of parameters describing data collection and refinement for gersdorffite and tetrahedrite-(Fe).

\begin{tabular}{|c|c|c|}
\hline Crystal data & Gersdorffite & Tetrahedrite-(Fe) \\
\hline Crystal size (mm) & $0.13 \times 0.08 \times 0.08$ & $0.08 \times 0.07 \times 0.06$ \\
\hline Space group & $P 2{ }_{1} 3$ & $I-43 m$ \\
\hline$a(\AA)$ & $5.6968(7)$ & $10.3815(10)$ \\
\hline$V\left(\AA^{3}\right)$ & $184.88(7)$ & $1118.9(3)$ \\
\hline$Z$ & 4 & 2 \\
\hline \multicolumn{3}{|l|}{ Data collection and refinement } \\
\hline Radiation, wavelength $(\AA)$ & \multicolumn{2}{|c|}{$\operatorname{Mo} K \alpha, \lambda=0.71073$} \\
\hline Temperature $(\mathrm{K})$ & \multicolumn{2}{|c|}{$293(2)$} \\
\hline Maximum observed $2 \theta\left(^{\circ}\right)$ & 54.57 & 62.85 \\
\hline Measured reflections & 535 & 2879 \\
\hline Unique reflections & 150 & 375 \\
\hline Reflections $F_{o}>4 \sigma\left(F_{o}\right)$ & 148 & 342 \\
\hline$R_{\text {int }}$ after absorption correction & 0.0309 & 0.0468 \\
\hline$R \sigma$ & 0.0284 & 0.0310 \\
\hline \multirow{3}{*}{ Range of $h, k, l$} & $-7 \leq h \leq 6$ & $-15 \leq h \leq 14$ \\
\hline & $-4 \leq k \leq 7$ & $-9 \leq k \leq 15$ \\
\hline & $-5 \leq l \leq 6$ & $-12 \leq l \leq 15$ \\
\hline$R\left[F_{O}>4 \sigma F_{O}\right]$ & 0.0349 & 0.0270 \\
\hline$R$ (all data) & 0.0352 & 0.0329 \\
\hline$w R\left(\right.$ on $\left.F_{o}^{2}\right)$ & 0.0837 & 0.0570 \\
\hline Goodness of fit & 1.322 & 1.074 \\
\hline Number of least-squares parameters & 12 & 22 \\
\hline \multirow[t]{2}{*}{ Maximum and minimum residual peak $\left(e / \AA^{3}\right)$} & 0.99 [at $0.90 \AA$ from $\mathrm{As}(2)]$ & 0.53 [at $0.24 \AA$ from $X(3)]$ \\
\hline & $-0.76[$ at $1.60 \AA$ from $\mathrm{As}(2)]$ & -0.69 [at $0.73 \AA$ from $X(3)$ ] \\
\hline
\end{tabular}

Table 4. Sites, site occupancy factor (s.o.f.), fractional atomic coordinates, and equivalent isotropic displacement parameters (in $\AA^{2}$ ) for gersdorffite and tetrahedrite-(Fe).

\begin{tabular}{llrrrr}
\hline \multicolumn{6}{l}{ Gersdorffite } \\
Site & s.o.f. & $x / a$ & $y / b$ & $z / c$ & $U_{\text {eq }}$ \\
\hline $\mathrm{Ni}$ & $\mathrm{Ni}_{1.00} \mathrm{As}_{0.14(2)}$ & $0.0059(4)$ & $0.0059(4)$ & $0.0059(4)$ & $0.0117(7)$ \\
$\mathrm{S}$ & $\mathrm{S}_{0.86(2)}$ & $0.3814(2)$ & $0.3814(2)$ & $0.3814(2)$ & $0.0121(6)$ \\
$\mathrm{As}$ & $\mathrm{As}_{1.00}$ & & & & \\
\hline Tetrahedrite-(Fe) & $x / a$ & $y / b$ & $z / c$ & $U_{\text {eq }}$ \\
\hline Site & s.o.f. & 0 & 0 & $0.7830(3)$ & $0.0613(11)$ \\
$M(2)$ & $\mathrm{Cu}_{1.001(16)}$ & $1 / 4$ & $1 / 2$ & 0 & $0.0241(7)$ \\
$M(1)$ & $\mathrm{Cu}_{0.971(14)}$ & $0.26767(6)$ & $0.26767(6)$ & $0.26767(6)$ & $0.0196(3)$ \\
$X(3)$ & $\mathrm{Sb}_{0.93(4)} \mathrm{As}_{0.07(4)}$ & $0.11620(17)$ & $0.11620(17)$ & $0.3614(2)$ & $0.0179(6)$ \\
$\mathrm{S}(1)$ & $\mathrm{S}_{1.00}$ & 0 & 0 & 0 & $0.0218(16)$ \\
$\mathrm{S}(2)$ & $\mathrm{S}_{1.00}$ & & & & \\
\hline
\end{tabular}

tetrahedrite. In regards to this latter mineral, the chemical analysis by Triscari (1985) led to the chemical formula $\left(\mathrm{Cu}_{6.00} \mathrm{Ag}_{0.05}\right)_{\Sigma 6.05}\left(\mathrm{Cu}_{4.07} \mathrm{Fe}_{1.36} \mathrm{Zn}_{0.57}\right)_{\Sigma 6.00}\left(\mathrm{Sb}_{3.90}\right.$

$\left.\mathrm{As}_{0.05}\right)_{\Sigma 3.95} \mathrm{~S}_{12.33}$, agreeing with our classification as tetrahedrite-(Fe) but showing a significant $\mathrm{S}$ deficit. The unitcell parameter reported by Triscari (1985), $a=10.377 \AA$, can be compared with that refined in this work, i.e., $a=10.382 \AA$. Triscari (1985) attributed minor $\mathrm{Sb}$ and $\mathrm{Cu}$ detected in gersdorffite to admixed tetrahedrite- $(\mathrm{Fe})$. In our opinion, this interpretation may be wrong, since such an $\mathrm{Sb}$ content should be associated with a corresponding high $\mathrm{Cu}$ content, in agreement with tetrahedritegroup mineral stoichiometry. On the contrary, it is likely that $\mathrm{Sb}$ replaces $\mathrm{As}$ and $\mathrm{S}$, as observed in our study. 
Table 5. Selected bond distances (in $\AA$ ) for gersdorffite and tetrahedrite-(Fe).

\begin{tabular}{rlr|rlr}
\hline \multicolumn{2}{c|}{ Gersdorffite } & \multicolumn{3}{c}{ Tetrahedrite-(Fe) } \\
\hline $\mathrm{Ni}$ & $-\mathrm{S}$ & $2.349(2) \times 3$ & $M(1)$ & $-\mathrm{S}(1) \times 4$ & $2.3354(14)$ \\
& - As & $2.405(2) \times 3$ & $M(2)$ & $-\mathrm{S}(2)$ & $2.253(3)$ \\
& Average & 2.114 & & $-\mathrm{S}(1) \times 2$ & $2.271(3)$ \\
As & $-\mathrm{S}$ & $2.313(4)$ & $X(3)$ & $-\mathrm{S}(1) \times 3$ & $2.428(2)$ \\
\hline
\end{tabular}

(a)

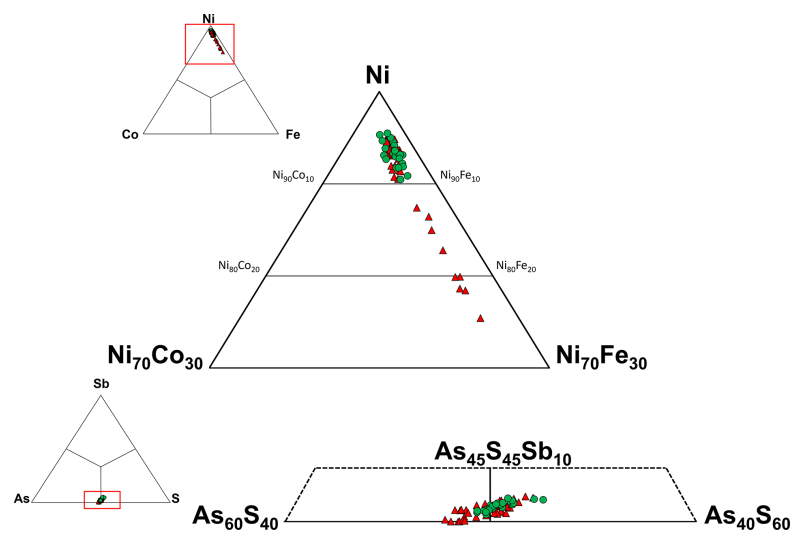

Figure 4. Compositional diagrams showing the chemical variability of gersdorffite from the Contrada Zillì. Green circles represent spot analyses performed in crystal cores, whereas red triangles correspond to crystal rims.

Recalculating the chemical data of gersdorffite given in Triscari (1985) on the basis of $3 \mathrm{apfu}$, the chemical formula $\left(\mathrm{Ni}_{0.89} \mathrm{Fe}_{0.05} \mathrm{Co}_{0.01}\right)_{\Sigma 0.95}\left(\mathrm{As}_{0.90} \mathrm{Sb}_{0.09}\right)_{\Sigma 0.99} \mathrm{~S}_{1.05}$ can be obtained. In this way, the Sb-content calculated from the data of Triscari (1985) agrees with that found in our study. It is interesting to note that $\mathrm{Sb}$ is correlated with $\mathrm{Bi}$. This latter element was not detected by Triscari (1985), although its occurrence in the ore deposits of the Peloritani Mountains was previously reported (e.g., Donati et al., 1978). The presence of $\mathrm{Bi}$ in gersdorffite is an uncommon feature. For instance, Henning et al. (1997) reported up to $0.12 \mathrm{wt} \%$ in gersdorffite from the Eastern Cape province, Republic of South Africa, whereas Voudouris et al. (2018) found up to $0.18 \mathrm{wt} \% \mathrm{Bi}$ in samples from the Clemence deposit, in the Kamariza mining district, Greece. The Bi content of gersdorffite from Contrada Zillì (up to $2.76 \mathrm{wt} \%$ ) can be compared with that reported by Grapes and Challis (1999) from the Calphurnia Creek, northwest Nelson, New Zealand, i.e., $2.80 \mathrm{wt} \%$. However, to the best of our knowledge, the highest Bi content reported in gersdorffite was found by Persuad et al. (1988) in samples from the Dawn Lake U-Ni deposit, Saskatchewan, Canada, i.e., $14.53 \mathrm{wt} \%$.

The unit-cell parameter of gersdorffite from Contrada Zillì, $a=5.697 \AA$, is in accordance with that given by Triscari (1985), i.e., $a=5.694 \AA$ A Such values are close to that determined by Petruk et al. (1971) for stoichiometric Ni-
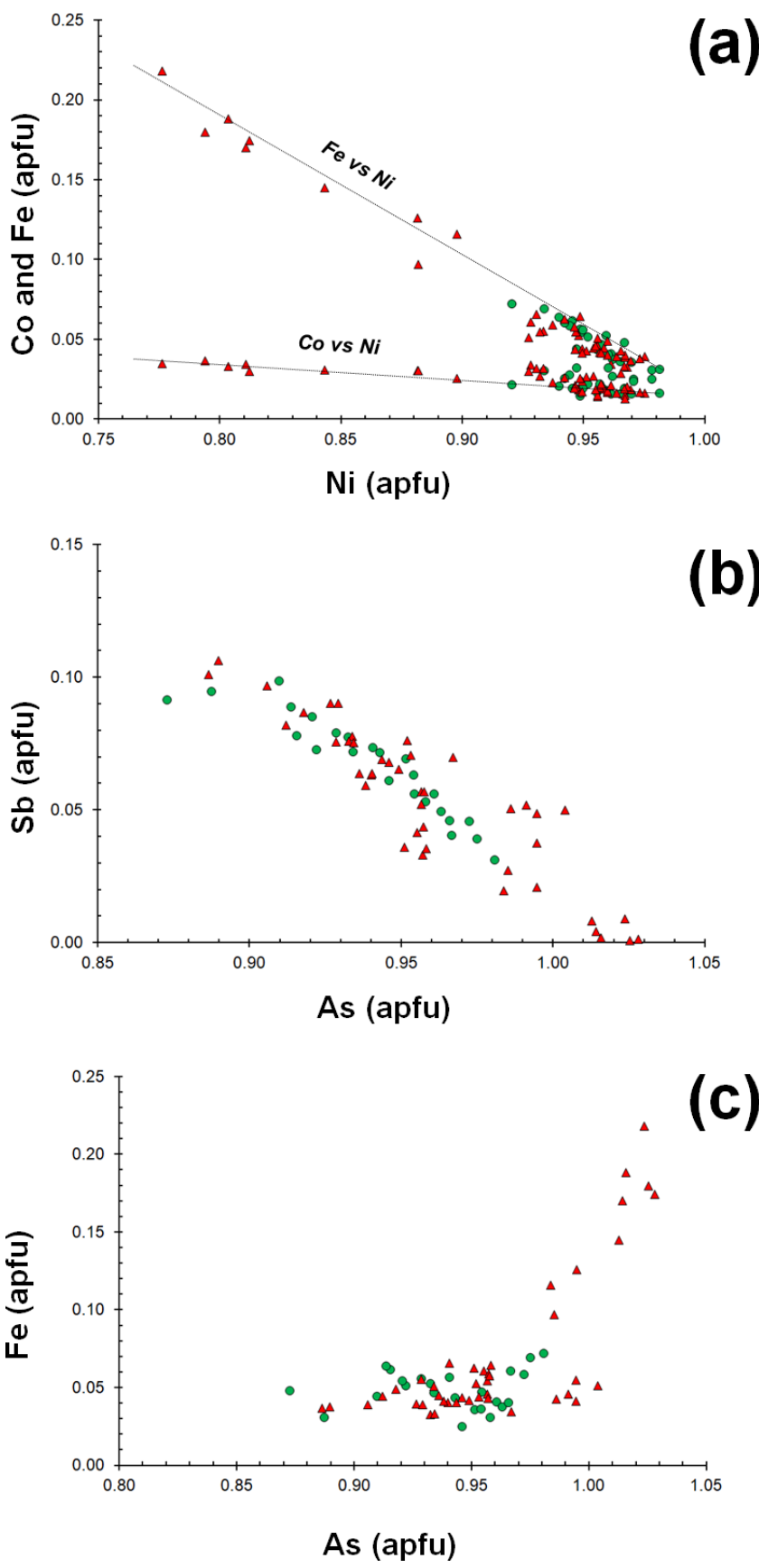

Figure 5. Relations between chemical constituents in gersdorffite from the Contrada Zillì. Same symbols as in Fig. 4.

AsS, i.e., $a=5.6939 \AA$. The observed unit-cell parameter of the Sicilian sample is likely the result of the opposite effect of the (Fe,Co)-to-Ni substitution, favoring a contraction of the unit-cell size, and the (As,Sb)-to-S replacement, inducing a cell expansion. Finally, the ordered $P 2{ }_{1} 3$ ullmannite-type structure proposed by Triscari (1985) is confirmed.

Space group symmetry and chemical composition, with only minor $\mathrm{Fe}$ and $\mathrm{Co}$ replacing $\mathrm{Ni}$, as well as an As: $\mathrm{S}$ atomic ratio close to one, agrees with a low-temperature 

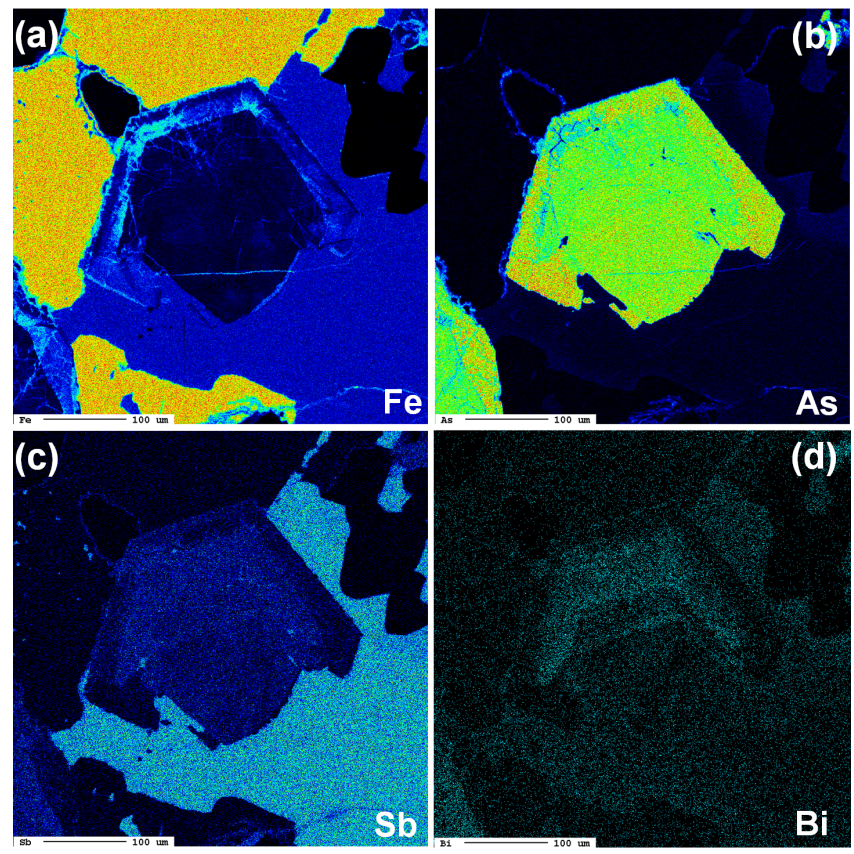

Figure 6. X-ray maps showing the distribution of Fe (a), As (b), $\mathrm{Sb}(\mathbf{c})$, and $\mathrm{Bi}(\mathbf{d})$, collected on the same zoned crystal in Fig. 3a.

crystallization, in accordance with the experimental works of Klemm (1965) and Hem and Makovicky (2004). However, these studies were performed on dry systems, and it is not possible to directly propose crystallization temperatures for hydrothermal systems (e.g., Mederski et al., 2021). In this respect, it may useful a comparison between gersdorffite from the Peloritani Mountains and that from the Monte Arsiccio mine, Apuan Alps (unpublished data). At this latter locality, gersdorffite has chemical composition $\left(\mathrm{Ni}_{0.61} \mathrm{Fe}_{0.39}\right) \mathrm{As}_{0.99} \mathrm{~S}_{1.01}$ and crystallizes in the Pa3 polytype. Such a high-Fe content and pyrite-type disordered structure are compatible with a crystallization in a relatively high-temperature environment, in accordance with an estimated trapping temperature of $400-420^{\circ} \mathrm{C}$ proposed by $\mathrm{Bi}$ agioni et al. (2020c) for fluid inclusions sampled in the same veins where gersdorffite was identified. Such values are similar to those proposed by Costagliola et al. (1998) for the nearby Pollone mine, i.e., ca. $450^{\circ} \mathrm{C}$ at $0.35-0.40 \mathrm{GPa}$. Likely, gersdorffite from the Peloritani Mountains crystallized well below $T=400^{\circ} \mathrm{C}$.

Chemical zoning is a common feature observed in gersdorffite from several localities worldwide (e.g., Fanlo et al., 2006; Mederski et al., 2021). As shown in Fig. 6, crystals from Contrada Zillì are characterized by two distinct domains: a core relatively enriched in $\mathrm{Sb}$ and $\mathrm{Bi}$ is mantled by a (Fe,As)-rich rim. Different hypotheses could explain such a zoning. For instance, this could be the result of a two-step crystallization in slightly different physicochemical conditions. This could agree with the results of Censi and Ferla (1982/1983) who, on the basis of isotopic data, suggested the occurrence of multiple hydrothermal events recorded in the Peloritani Mountains. Moreover, in some cases, gersdorffite crystals seem to be corroded and replaced by tetrahedrite(Fe). This could be the result of a further hydrothermal event, possibly leading to the remobilization of As and the addition of $\mathrm{Cu}$.

\section{Conclusions}

The crystal-chemical study of samples from Contrada Zillì (Fiumedinisi, Messina Province) containing an assemblage of gersdorffite, tetrahedrite-(Fe), and chalcopyrite, along with other minor accessory phases, improved our knowledge on the ore mineralogy of the Peloritani Mountains, refining the previous knowledge on some of these minerals reported by Triscari (1985). Moreover, the first finding of aikinite in the ore deposits of the Calabro-Peloritani Arc is here reported. This is clearly related to the Bi-bearing nature of these ore bodies, also shown by the detectable amounts of $\mathrm{Bi}$ revealed in gersdorffite and the previously known occurrences of bismuthinite (e.g., Donati et al., 1978).

Crystal-chemical and textural features of gersdorffite open several questions about the geological evolution of the ore deposits of the Peloritani Mountains. Whereas its lowtemperature crystallization seems very likely, other details remain unclear. For instance, the chemical zoning suggests a polyphasic crystallization, in agreement with some authors who proposed the superposition of several hydrothermal events (e.g., Censi and Ferla, 1982/1983). However, their timing is unknown. According to Triscari (1985), the vein system cropping out at Contrada Zillì is discordant with respect to the primary strata-bound sulfide ores and may be associated with the late-stage evolution of the area, but the role of Variscan and Alpine orogenic events in producing the current mineralogy and ore textures is debatable. For instance, Saccà et al. (2003) related the vein formation to late Variscan hydrothermal processes, whereas the role of the Alpine history is undefined. However, euhedral crystals of some sulfides have been observed in vugs (e.g., tetrahedrite crystals from the San Carlo mine - Musumeci, 1958); consequently, the role of Alpine history may be undervalued.

Further mineralogical studies, coupling single-crystal Xray diffraction and electron microprobe data, along with an accurate sampling of ore bodies, will likely be able to improve our knowledge on the genesis and evolution of the ore deposits hosted in the Variscan basement of the CalabroPeloritani Arc, an area sharing several geological similarities with other Italian areas well known for the occurrence of interesting ore minerals such as Sardinia and the Apuan Alps. 
Data availability. The Crystallographic Information File data of gersdorffite and tetrahedrite-(Fe) are available in the Supplement.

Supplement. The supplement related to this article is available online at: https://doi.org/10.5194/ejm-33-717-2021-supplement.

Author contributions. DM conceived and designed the experiments; DM and CB carried out the single-crystal data collections; FZ collected electron microprobe data. DM and CB analyzed the results and wrote the article, with input from FZ.

Competing interests. Some authors are members of the editorial board of European Journal of Mineralogy. The peer-review process was guided by an independent editor, and the authors have also no other competing interests to declare.

Disclaimer. Publisher's note: Copernicus Publications remains neutral with regard to jurisdictional claims in published maps and institutional affiliations.

Acknowledgements. Technical assistance during SEM-EDS study by Randa Anis Ishak (C.I.S.U.P.) is kindly acknowledged. The University Centrum for Applied Geosciences (UCAG) is thanked for the access to the E.F. Stumpfl electron microprobe laboratory. The comments of Yves Moëlo and an anonymous reviewer helped us in improving the paper.

Financial support. This research received support from the Ministero dell'Istruzione, dell'Università e della Ricerca through the project PRIN 2017 “TEOREM - deciphering geological processes using Terrestrial and Extraterrestrial ORE Minerals" (project no. 2017AK8C32).

Review statement. This paper was edited by Reto Gieré and reviewed by Yves Moëlo and one anonymous referee.

\section{References}

Andreasen, J. W., Makovicky, E., Lebech, B., and Karup Møller, S.: The role of iron in tetrahedrite determined by Rietveld refinement of neutron powder diffraction data, Phys. Chem. Mineral., 35, 447-454, 2008.

Artini, E.: Note mineralogiche sulla Valsassina, Atti Soc. Ital. Sci. Nat., Mus. Civ. Stor. Nat. Milano, 42, 101-11, 1903.

Baldanza, B. Z.: Contributo alla conoscenza dei minerali metalliferi dei Monti Peloritani - (Gli affioramenti), Notizie di Mineralogia Siciliana e Calabrese, 2, 23-40, 1948.

Bayliss, P.: The crystal structure of disordered gersdorffite, Am. Mineral., 53, 290-293, 1968.
Bayliss, P.: X-ray data, optical anisotropism, and thermal stability of cobaltite, gersdorffite, and ullmannite, Mineral. Mag., 37, 26-33, 1969.

Bayliss, P.: A further crystal structure refinement of gersdorffite, Am. Mineral., 67, 1058-1064, 1982.

Bayliss, P. and Stephenson, N. C.: The crystal structure of gersdorffite, Mineral. Mag., 36, 38-42, 1967.

Bayliss, P. and Stephenson, N. C.: The crystal structure of gersdorffite (III), a distorted and disordered pyrite structure, Mineral. Mag., 36, 940-947, 1968.

Benvenuti, M.: Ni-sulphides from Bottino mine (Tuscany, Italy), Eur. J. Mineral., 3, 79-84, https://doi.org/10.1127/ejm/3/1/0079, 1991.

Biagioni, C., George, L. L., Cook, N. J., Makovicky, E., Moëlo, Y., Pasero, M., Sejkora, J., Stanley, C. J., Welch, M. D., and Bosi, F.: The tetrahedrite group: Nomenclature and classification, Am. Mineral., 105, 109-122, 2020a.

Biagioni, C., Sejkora, J., Musetti, S., Velebil, D., and Pasero, M.: Tetrahedrite-(Hg), a new "old" member of the tetrahedrite group, Mineral. Mag., 84, 584-592, 2020b.

Biagioni, C., D’Orazio, M., Fulignati, P., George, L. L., Mauro, D., and Zaccarini, F.: Sulfide melts in ore deposits from low-grade metamorphic settings: Insigths from fluid and Tlrich sulfosalt microinclusions from the Monte Arsiccio mine (Apuan Alps, Tuscany, Italy), Ore Geol. Rev., 123, 103589, https://doi.org/10.1016/j.oregeorev.2020.103589, 2020c.

Bossolasco, M. and Bonetti, A.: Le possibilità minerarie della provincia di Messina, Geofisica pura e applicata 2, 60-71, 1940.

Brese, N. E. and O'Keeffe, M.: Bond-valence parameters for solids, Acta Crystallogr., B47, 192-197, 1991.

Bruker AXS Inc.: APEX 3. Bruker Advanced X-ray Solutions, Madison, Wisconsin, USA, 2016.

Carbone, S., Messina, A., and Lentini, F.: Note illustrative della Carta Geologica d'Italia alla scala 1:50.000. Foglio 601 Messina-Reggio di Calabria, Serv. Geol. Ital., 1-179, 2007.

Carrozzini, B., Garavelli, C. L., and Vurro, F.: Tetrahedrite (supposed Frigidite) and associated Ni minerals from Frigido mine (Apuane Alps), Period. Mineral., 60, 5-14, 1991.

Censi, P. and Ferla, P.: I marmi dei Monti Peloritani. Composizione isotopica dell'ossigeno e del carbonio e ricostruzione degli ambienti formazionali, Rend. Soc. Ital. Mineral. Petrol., 38, 11011117, 1982/1983.

Costagliola, P., Benvenuti, M., Lattanzi, P., and Tanelli, G.: Metamorphogenic barite-pyrite $(\mathrm{Pb}-\mathrm{Zn}-\mathrm{Ag})$ veins at Pollone, Apuane Alps, Tuscany: vein geometry, geothermobarometry, fluid inclusions and geochemistry, Mineral. Petrol., 62, 29-60, 1998.

Dessau, G.: I minerali dei filoni a nichelio e cobalto dell'Arburese (Sardegna), Period. Mineral., 7, 21-39, 1936.

Donati, G., Stagno, F., and Triscari, M.: Ricerche sulle mineralizzazioni metallifere dei M. Peloritani. III) Giacimenti delle C.de S. Carlo, Montagne e viciniori presso Fiumedinisi (Messina), Atti Accad. Peloritana Pericolanti, Cl. Sc. Mat. Fis. Nat., 56, 177-238, 1978.

Fanlo, I., Subías, I., Gervilla, F., and Manuel, J.: Textures and compositional variability in gersdorffite from the Crescencia $\mathrm{Ni}-(\mathrm{Co}-$ U) showing, Central Pyrenees, Spain: primary deposition or reequilibration?, Can. Mineral., 44, 1513-1528, 2006. 
Ferla, P.: Inquadramento geologico-petrografico delle mineralizzazioni metallifere nei Monti Peloritani (Sicilia), Rend. Soc. Ital. Min. Petr., 38, 1075-1091, 1982/1983.

Ferla, P. and Omenetto, P.: Metallogenetic evolution of Peloritani Mountains (NE-Sicily): a summary, Mem. Soc. Geol. It., 55, 293-297, 2000.

Fleet, M. E. and Burns, P. C.: Structure and twinning of cobaltite, Can. Mineral., 28, 719-723, 1990.

Garuti, G., Bea, F., Zaccarini, F., and Montero, P.: Age, geochemistry and petrogenesis of the ultramafic pipes in the Ivrea Zone, NW Italy, J. Petrol., 42, 433-457, 2001.

Grapes, R. H. and Challis, G. A.: Gersdorffite with pentlandite, violarite, pyrrhotite, and pyrite, nortwest Nelson, New Zealand, New Zealand J. Geol. Geophys., 42, 189-204, 1999.

Hem, S. R. and Makovicky, E.: The system Fe-Co-Ni-As-S. II. Phase relations in the $(\mathrm{Fe}, \mathrm{Co}, \mathrm{Ni}) \mathrm{As}_{1.5} \mathrm{~S}_{0.5}$ section at $650^{\circ}$ and $500^{\circ} \mathrm{C}$, Can. Mineral., 42, 63-86, 2004.

Henning, A., van der Westhuizen, W. A., de Bruiyn, H., and Beukes, G. J.: Hydrothermal Cu-Ni-Au-Ag mineralization in a granodiorite sill north of Cradock, Republic of South Africa, Mineralium Dep., 32, 410-418, 1997.

Jervis, W. P.: I tesori sotterrannei dell'Italia: Regione delle Isola Sardegna e Sicilia, Ermanno Loescher, Torino, 540 pp., 1881.

Johnson, M. L. and Burnham, C. W.: Crystal structure refinement of an arsenic-bearing argentian tetrahedrite, Am. Mineral., 70, 165-170, 1985.

Klemm, D. D.: Synthesen und Analysen in den Dreiecksdiagrammen FeAsS-CoAsS-NiAsS und $\mathrm{FeS}_{2}-\mathrm{CoS}_{2}-\mathrm{NiS}_{2}$, Neues Jb. Miner. Abh., 103, 205-255, 1965.

La Valle, G.: Su di alcuni nuovi minerali cobaltiferi e nichiliferi nella provincia di Messina, Atti R. Accad. Lincei, 7, 68-71, 1898.

La Valle, G.: I giacimenti metalliferi di Sicilia in provincia di Messina, Tipografia Fratelli Fugazotto, Messina, 83 pp., 1899.

Lovisato, D.: Sulla senarmontite di Nieddoris in Sardegna e sui minerali che l'accompagnano in quella miniera, Rend. R. Accad. Lincei, 3, 82-89, 1894.

Mederski, S., Wojsław, M., Pršek, J., Majzlan, J., Kiefer, S., and Asllani, B.: A geochemical study of gersdorffite from the Trepça Mineral Belt, Vandar Zone, Kosovo, J. Geosci., 66, 97-115, 2021.

Messina, A., Somma, R., Macaione, E., Carbone, G., and Careri, G: Peloritani continental crust composition (Southern Italy): geological and petrochemical evidence, Boll. Soc. Geol. It., 123, 405-441, 2004.

Moroni, M., Rossetti, P., Naitza, S., Magnani, L., Ruggieri, G., Aquino, A., Tartarotti, P., Franklin, A., Ferrari, E., Castelli, D., Oggiano, G., and Secchi, F.: Factors controlling hydrothermal nickel and cobalt mineralization - Some suggestions from historical ore deposits in Italy, Minerals, 9, 429, https://doi.org/10.3390/min9070429, 2019.

Musumeci, T.: Notizie sui cristalli delle mineralizzazioni metallifere dei Monti Peloritani, Rend. Soc. Ital. Min. Petrol., 14, 277$286,1958$.
Oteri, F., Saccà, C., Stagno, F., and Triscari, M.: Confronto tra composizione chimica e modalità giaciturali di alcuni minerali metalliferi dei Monti Peloritani (Sicilia N.E.), Rend. Soc. Ital. Min. Petrol., 41, 41-52, 1986.

Persuad, E. C. R., Morton, R.D., and Launspach, S.: Bismuthian gersdorffites from the Dawn Lake U-Ni deposit, N. Saskatchewan, Canada, Neues Jb. Miner., Monat., 7, 309-323, 1988.

Petruk, W., Harris, D. C., and Stewart, J. M.: Characteristics of the arsenides, sulpharsenides, and antimonides, Can. Mineral., 11, 150-186, 1971.

Rodolico, F.: Studio a luce riflessa di alcuni minerali italiani, Period. Mineral., 11, 1-14, 1940.

Saccà, C., Saccà, D., Nucera, P., and Somma, R.: Gold-bearing polymetalliferous mineralization in the Central Peloritani Mts. (NE Sicily, Italy), Boll. Soc. Geol. It., 122, 503-509, 2003.

Saccà, C., Saccà, D., and Nucera, P.: Le mineralizzazioni dei Monti Peloritani. Storia e attualità, Aracne Editrice, Roma, 300 pp., 2015.

Seguenza, G.: Ricerche mineralogiche sui filoni metalliferi di Fiumedinisi e suoi dintorni in Sicilia, Stamperia Antonino D’Amico Arena, Messina, 70 pp., 1856.

Sheldrick, G. M.: Crystal structure refinement with SHELXL, Acta Crystallogr., C71, 3-8, 2015.

Traina, E.: Sull'anglesite dei giacimenti metalliferi della provincia di Messina, Atti R. Accad. Lincei, 14, 220-223, 1905.

Triscari, M.: A first occurrence of gersdorffite in the Peloritani Mts. (Sicily N.E.), Rend. Soc. Ital. Min. Petrol., 40, 289-294, 1985.

Triscari, M. and Saccà, C.: Scheelite at the "San Carlo" Sb-CuAg mine, Fiumedinisi, Messina, Italy, Mineral. Petrogr. Acta, 26, 159-168, 1982.

Triscari, M. and Saccà, C.: Contributo alla conoscenza dei minerali metalliferi dei Monti Peloritani (Sicilia N.E.) VI) La boulangerite, Rend. Soc. Ital. Min. Petrol., 39, 145-154, 1984.

Voudouris, P., Mavrogonatos, C., Rieck, B., Kolitsch, U., Spry, P. G., Scheffer, C., Tarantola, A., Vanderhaeghe, O., Galanos, E., Melfos, V., Zaimis, S., Soukis, K., and Photiades, A.: The gersdorffite-bismuthinite-native gold association and the skarn-porphyry mineralization in the Kamariza mining district, Lavrion, Greece, Minerals, 8, 531, https://doi.org/10.3390/min8110531, 2018.

Welch, M. D., Stanley, C. J., Spratt, J., and Mills, S. J.: Rozhdestvenskayaite, $\mathrm{Ag}_{10} \mathrm{Zn}_{2} \mathrm{Sb}_{4} \mathrm{~S}_{13}$, and argentotetrahedrite, $\mathrm{Ag}_{6} \mathrm{Cu}_{4}\left(\mathrm{Fe}^{2+}, \mathrm{Zn}\right)_{2} \mathrm{Sb}_{4} \mathrm{~S}_{13}$ : two Ag-dominant members of the tetrahedrite group, Eur. J. Mineral., 30, 1163-1172, https://doi.org/10.1127/ejm/2018/0030-2773, 2018.

Wilson, A. J. C. (Ed.): International Tables for Crystallography Volume C: Mathematical, Physical and Chemical Tables, Kluwer Academic Publishers, Dordrecht, The Netherlands, 1992. 